\title{
How many doctors should we train for Sri Lanka? System dynamics modelling of training needs
}

\author{
Dileep De Silva
}

\begin{abstract}
Introduction Over the years, Sri Lanka has achieved remarkable health gains for the money spent on health. Currently about 1450 doctors enter the health system annually. While some advocate opening up of new medical schools to address an apparent shortage of doctors in the country, others argue against it.

Objective To identify the number of doctors Sri Lanka need.

Methodology System dynamics, an analytical modelling approach and a methodology for studying complex feedback systems was used. Two sub models of "need" and "supply" were developed and simulated for a period of 15 years from 2017 to 2032
\end{abstract}

Results At present the doctor to population ratio is 1:671 and $91 \%$ of the need has been met. This study shows that currently there is a shortage of doctors in the country. However, the supply will match the need by $2025 / 26$. Increasing the number of doctors, will result in oversupply of doctors towards the latter part of the next decade.

Conclusions There is no acute necessity to open up new Medical Schools. However comprehensive health workforce analysis needs to be done once in 5 years and the number of doctors to be trained, decided accordingly.

Ceylon Medical Journal 2017; 62: 233-37

DOI: http://doi.org/10.4038/cmj.v62i4.8573

\section{Introduction}

Sri Lanka is a developing country with GDP per capita of USD 3900 , of which only $3.2 \%$ is spent on Health [1]. However, Sri Lanka's health gains are remarkable for the amount of money spent on Health care. For example in Sri Lanka the maternal mortality ratio is 33 per 100,000 live births, infant mortality ratio is 8.2 per 1000 live births and life expectancy at birth is high i.e. 72 years for males and 78 years for females [2].
Sri Lankan Health care delivery system includes both public and private sectors. Public sector health care delivery is free of charge for the end user while in the private sector user fees are charged and it is driven by market forces. Doctors employed in the state sector are also entitled to do private practice after hospital working hours.

Public health sector is the key player in health care delivery accounting for $55 \%$ of the annual health expenditure while the private sector contributes around $43 \%$ [1].

The state provides free education including university education. However medical school admission is very competitive as positions in the state medical schools are limited. There are 8 medical schools in the state universities and one Defense University, altogether producing around 1200 doctors annually [3]. There is one private medical school, however Sri Lanka Medical Council (SLMC) has still not recognized its degree, to register graduates as medical practitioners.

As evidenced by recent strikes from student bodies, trade unions, professional bodies and civil organizations, there is very strong opposition for private medical education in Sri Lanka. The opponents' claim that the number of doctors produced by the state medical schools is enough for the country; hence if private sector is allowed to produce doctors there could be an oversupply. Furthermore, there are concerns regarding quality of unregulated private medical education. Nonetheless proponents claim that Sri Lanka need more doctors, hence the need for private medical education.

According to the Sri Lanka Medical Council, annually around 250 Sri Lankan students obtain medical degrees from foreign universities and return to the country. The number of students returning with foreign degrees have increased over the past few years. These students have to sit for a qualifying examination conducted by the Sri Lanka Medical Council, before they are registered as doctors to practice medicine in Sri Lanka [4].

Correspondence: DDS, e-mail: <dileepdenta@yahoo.com>. Received 6 July 2017 and revised version accepted 10 October 2017. 
Once a doctor completes the mandatory internship of one year in a recognized government hospital, they have several career pathways; join the Ministry of Health as medical officers, the university system as academics, the Defense Forces as military doctors, the private sector or Migrate to another country.

The number of doctors the country needs also depends on demand dynamics, which in turn depend on population profile, disease patterns and existing or planned health system facilities.

Workforce planning is a multi-dimensional concept involving both internal and external factors of an organization, while taking a strategic holistic approach [5]. Moreover, healthcare provision cannot be understood by looking at various factors in isolation [6].

Currently whether the country needs more medical schools, is a key debate. However, no studies have been done in Sri Lanka in the recent past, using a scientific tool or a methodology to identify the number of doctors the country should train. The author in an attempt to answer this question, describes a System Dynamic Model to predict how many doctors should be trained in Sri Lanka. System dynamics is an analytical modelling approach and a methodology for studying complex feedback systems [7]. It is an aid to understanding the behaviour of complex systems over time [8].

\section{Methodology}

Several studies were done to quantify some input parameters of the model. These sample studies consisted of focus group discussions held at district level with relevant experts.

Data pertaining to the number of medical students and staff in the state faculties and Kotelawala Defense University (KDU) were obtained from the respective Deans. Number of foreign qualified graduates passing the Examination for Registration to Practice Medicine in Sri Lanka (ERPM) was obtained from the SLMC. The number of students going abroad to study medicine was obtained by triangulation of data from, University Grant Commission, student recruiting agencies, foreign universities and local banks. Data pertaining to private hospitals and doctors employed in the private sector including general medical practitioners were collected from sample studies and the College of General Practitioners.

By analyzing the existing number of doctors in different categories and their respective training rates, retirement rates, attrition rates and dual employment patterns; the availability (supply) of doctors was derived.

The Model also considered the health economic growth of the country and its impact on the state and private sector opportunities for doctors. Taking into account past trends it was assumed that the state health sector would grow by $5 \%$ annually and the private sector by $12 \%$ [9]. The number of doctors needed was analyzed considering population growth and the aging of the population. Finally, total requirement of doctors was calculated by triangulation of facility staffing norms prepared by the Ministry of Health and expert opinion of health care planners, provincial health authorities along with above parameters.

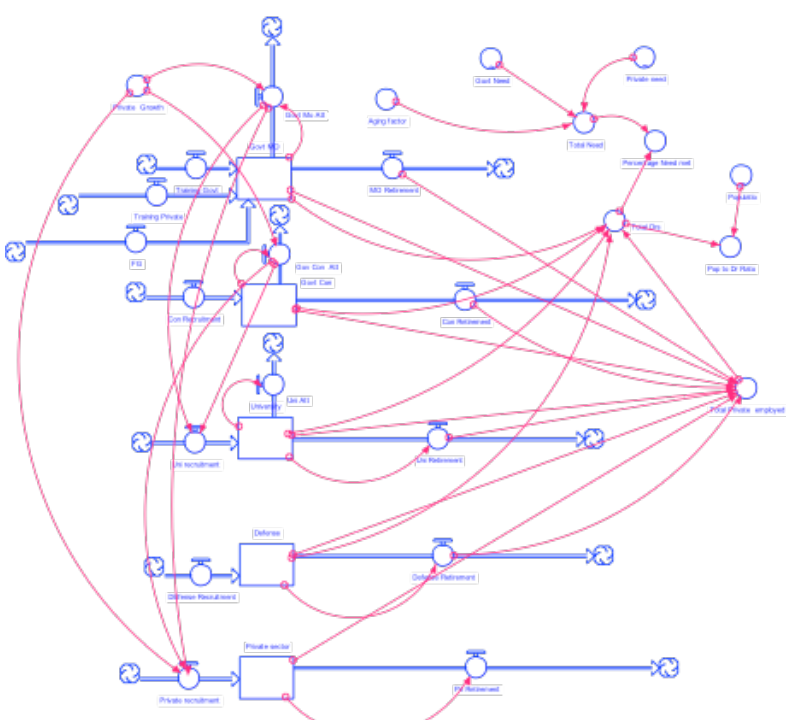

Figure 1. Snap shot of the SD model (using Stella software)

A System Dynamics (SD) model was developed for "Need" and "Supply" of doctors in Sri Lanka. Specialized computer software (Stella Version 9) was used for this purpose and the calculations were based on mathematical equations using Euler algorithm. The SD model is illustrated in Figure 1.

In this study, medical consultants were also included in the broader definition of doctors. Doctors working in different sectors were identified separately; such as government medical officers and consultants, university employed doctors, doctors working in the defense establishment and those in full time private practice.

In each of the doctor categories described above, training rate, attrition rate and retirement rate were considered. Attrition was defined as a doctor leaving a particular category before the age of retirement.

State sector employed doctors are allowed to engage in private practice after hospital working hours. This scenario was captured in the model. In all calculations, Full Time Equivalent (FTE) figures were considered. That is, for example, 100 part time doctors were considered $50 \mathrm{FTE}$ doctors.

Currently the 8 state medical faculties and Kotelawala Defense University produce around 1200 doctors annually. Until recently, nearly 230 students returned to the country after completing undergraduate medical courses from overseas. However, since of late the number of students going abroad for undergraduate medical education has increased substantially. Therefore, it is expected that the number of students returning annually to Sri Lanka after completing medical degrees abroad, will rise up to 300 by 2019 and reach around 500 by 2023 .

According to key informants and relevant websites there are around 940 students, in the solitary Private Medical School of the country [10]. This study assumed that they too will follow a similar career pathway, as those graduates 
Table 1. Input parameters of the model

\begin{tabular}{|c|c|c|}
\hline Input parameter & $\begin{array}{l}\text { Value as } \\
\text { at } 2017\end{array}$ & Data Source \\
\hline $\begin{array}{l}\text { Number of Doctors in the } \\
\text { Ministry of Health }\end{array}$ & 17,900 & $\begin{array}{l}\text { Ministry of } \\
\text { Health official } \\
\text { website }\end{array}$ \\
\hline $\begin{array}{l}\text { Number of consultants in } \\
\text { the Ministry of Health }\end{array}$ & 2,000 & $\begin{array}{l}\text { Ministry of } \\
\text { Health official } \\
\text { website }\end{array}$ \\
\hline $\begin{array}{l}\text { Number of doctors in } \\
\text { University academic staff } \\
\text { (medically qualified) }\end{array}$ & 625 & $\begin{array}{l}\text { Official } \\
\text { websites of } \\
\text { the Medical } \\
\text { Faculties }\end{array}$ \\
\hline $\begin{array}{l}\text { Number of doctors in } \\
\text { Defense Forces }\end{array}$ & 320 & $\begin{array}{l}\text { Official } \\
\text { websites and } \\
\text { key informants }\end{array}$ \\
\hline $\begin{array}{l}\text { Number of Doctors in } \\
\text { Full time Private sector; } \\
\text { including hospital } \\
\text { employed, GPs and } \\
\text { consultants }\end{array}$ & 3050 & $\begin{array}{l}\text { Sample studies } \\
\text { conducted for } \\
\text { this research }\end{array}$ \\
\hline $\begin{array}{l}\text { Percentage of Ministry of } \\
\text { Health doctors engaged } \\
\text { in Private Practice }\end{array}$ & $60 \%$ & $\begin{array}{l}\text { Sample studies } \\
\text { conducted for } \\
\text { this research }\end{array}$ \\
\hline $\begin{array}{l}\text { Percentage of Ministry } \\
\text { of Health consultants } \\
\text { engaged in Private } \\
\text { Practice }\end{array}$ & $90 \%$ & $\begin{array}{l}\text { Sample studies } \\
\text { conducted for } \\
\text { this research }\end{array}$ \\
\hline $\begin{array}{l}\text { Percentage of University } \\
\text { medically qualified } \\
\text { staff engaged in Private } \\
\text { Practice }\end{array}$ & $50 \%$ & $\begin{array}{l}\text { Sample studies } \\
\text { conducted for } \\
\text { this research }\end{array}$ \\
\hline $\begin{array}{l}\text { Percentage of Defense } \\
\text { establishment employed } \\
\text { doctors engaged in Pri- } \\
\text { vate Practice }\end{array}$ & $60 \%$ & $\begin{array}{l}\text { Sample studies } \\
\text { conducted for } \\
\text { this research }\end{array}$ \\
\hline
\end{tabular}

returning home with foreign degrees. It is expected that these students to graduate within the next 5-6 years.

The future of this institution is not clear and it was assumed that it will continue in the future either as a state Medical Faculty, fee levying non-profit organization, Government Private Partnership or as a Private Institution with an annual intake of around 100 students.

Currently, on average, out of 1450 who complete internship, around 1200 are employed by the Minister of Health, while around 220 seek employment in the private sector or migrate. The balance 30 make a career either in the University or the defense forces.

This study envisaged that the Government has plans to open up a Medical Faculty at Wayaba University in Kuliyapitiya in the North Western Province. It assumed that this Faculty will produce around 100 doctors annually to the system from 6 years hence.
There are around 19,900 doctors including consultants, working full time in the Ministry of Health [11]. Around 3050 are either full time General Medical Practitioners or are doctors and consultants employed full time in the private sector. The defence establishment has about 320 and the University system about 625 doctors in their permanent cadre [12].

Workforce dynamics are complicated as the state sector employed doctors are allowed to be engaged in private practice after hospital working hours. This includes doctors employed in the Minister of Health and those in the Universities and Ministry of Defense. Sample studies indicated that around $60 \%$ of state sector employed medical officers and $90 \%$ of consultants availed themselves of this privilege (table 1). Further confounding the workforce dynamics was the number of doctors entering specialist training programs, attrition from service and retirement. Majority of those who left or retired from state employment, joined the private sector either as part time or full time medical practitioners or consultants and worked until they reach around 70 years. System dynamics model developed in this research captured the parameters and rates given in table 1.

\section{Results}

The results from the simulation of the System Dynamics model for 15 years under different scenarios are given in table 2. The key output parameters were "percentage need met" and the "doctor to population ratio" (table 3 ).

\section{Discussion}

Healthcare delivery is a large, complex, socio-technical system, compounded with increasing complexities and growing uncertainties. Healthcare decision-making is complicated, as it involves different stakeholders in different strata with different perspectives. Therefore, health planners need to use systemic and systematic approaches to address them. In this context, Operational Research modelling techniques can be used to address many system problems encountered within the healthcare setting [13].

System Dynamics (SD) modelling has been used in a wide range of health applications. At one end of the spectrum is the use of System Dynamics modelling for a particular, specific disease. For example, screening for disease, developing emergency health and managing waiting times for treatment. At the other end of the spectrum is the application of System Dynamics in more complex and wider ranging issues in health care, such as assessing public health risks, or planning the healthcare workforce [14].

This paper describes a System Dynamics model for the supply of doctors in Sri Lanka, which fits well with the above described scope and applications of System Dynamics.

The success of Sri Lanka's health sector is largely due to its effective public delivery system, which provides both preventive and curative care at low cost. Government provides almost all preventive care and most in-patient treatment. 
Table 3. Key output parameters considered by the model

\begin{tabular}{|c|c|c|c|c|c|c|c|c|c|c|c|c|}
\hline & \multicolumn{3}{|c|}{ Continue status quo } & \multicolumn{3}{|c|}{$\begin{array}{c}\text { Increase intake by } \\
200\end{array}$} & \multicolumn{3}{|c|}{$\begin{array}{c}\text { Increase intake by } \\
400\end{array}$} & \multicolumn{3}{|c|}{$\begin{array}{l}\text { Increase intake by } \\
600\end{array}$} \\
\hline & 2017 & 2022 & 2027 & 2017 & 2022 & 2027 & 2017 & 2022 & 2027 & 2017 & 2022 & 2027 \\
\hline $\begin{array}{l}\text { Government } \\
\text { Doctors } \\
\text { (Medical } \\
\text { officers) }\end{array}$ & 17,900 & 23,912 & 29,853 & 17,900 & 23,912 & 30,639 & 17,900 & 23,912 & 31,426 & 17,900 & 23,912 & 32,214 \\
\hline $\begin{array}{l}\text { Private sector } \\
\text { Full time } \\
\text { doctors }\end{array}$ & 3050 & 3546 & 4246 & 3050 & 3546 & 4255 & 3050 & 3546 & 4437 & 3050 & 3546 & 4452 \\
\hline $\begin{array}{l}\text { Total FTE } \\
\text { doctors }\end{array}$ & 31,305 & 42,217 & 53,330 & 31,305 & 42,217 & 54,363 & 31,305 & 42,217 & 55,396 & 31,305 & 42,217 & 59,305 \\
\hline
\end{tabular}

Private health sector started to boom since 1980s. A few private hospitals primarily located in Colombo, deliver the bulk of private healthcare services, as the high fixed costs of operating healthcare facilities have served as a barrier to new entrants creating an oligopolistic market [9].

The WHO has identified a threshold in workforce density below which high coverage of essential interventions, including those necessary to meet the health related millennium development goals is very unlikely. Based on these estimates it has listed 57 countries with critical shortages. However Sri Lanka is not a one of those countries [15]. Therefore, it could be stated that, Sri Lanka currently has no acute shortage of health workforce including doctors.

Considering the different sectors and the dual employment pattern, there were around 31,000 "fulltime equivalent" doctors in Sri Lanka as at mid 2017. This gives a doctor to population ratio of around 1:671 and the percentage need met is $91 \%$.

When the "percentage need met" is less than $100 \%$ it means a shortage, when it equals $100 \%$ it is a point of saturation and when it exceeds $100 \%$ it implies an oversupply. Therefore, there is a shortage of doctors in Sri Lanka as at 2017.

However, if the current status quo continues Sri Lanka's doctor to population ratio will improve to $1: 534$ by 2022 , $1: 445$ by 2027 and $1: 389$ by 2032 ; while the percentage need met will increase from $97 \%$ in 2022 to $105 \%$ in 2027 and to $125 \%$ by 2032 .

The number of consultants in the country will increase from 1950 in 2017 to 3093 by 2022 and will reach 4271 by 2027 and 5259 by 2032 .

Continuing the status quo of intake, total number of full time doctors in the private sector will reach 3546 by 2022 and 4246 by 2027 , while total FTE doctors in the country will reach 42,217 by 2022 and 53,330 by 2027 and 63,714 by 2032 .
As illustrated in the table 3 even if the intake of medical students is to increase by 200,400 or 600 no change in the doctor to population ratio or percentage need met, will occur until 2023. This is due to long duration of training for medical undergraduates.

If the intake is increased by 200 from next year, need will match the supply in the year 2025. By 2027 percentage need met will be $107 \%$ and by 2032 it will be $128 \%$. Doctor to population ratio will also improve substantially over the years from 1:436 to 1:376 from 2027 to 2032 . If the intake is increased by 400 from next year, need will match the supply in the year 2025 , if the intake is increased by 600 it will still happen in the year 2025 . Above description highlights a clear oversupply of doctors in Sri Lanka which will begin in 2026/27 and to get worsen by 2032 .

However if the model is simulated without considering the private medical school and the proposed Wayaba Faculty, the doctor to population ratio will be 1:543, 1:463 and 1:397 in 2022, 2027 and 2032 respectively. Furthermore, percentage need met will be $95 \%$ in $2022,101 \%$ in 2027 and $121 \%$ in 2032 .

There are 625 medically qualified academics in permanent cadre posts in the 8 state medical faculties and Kotelawala Defence University. While accepting that no two state medical faculties are equal either in size or profile, it is shocking to note that while Medical Faculties of University of Colombo, Sri Jayawardenapura, Peradeniya and Kelaniya had medically qualified staff numbers of around 100 the Eastern University had only 14.

\section{Conclusion}

If status quo of intake of doctors is maintained, by 2025 Sri Lanka will have enough doctors. Even if the intake is increased by 600 within the next year, there will be no effect on the system until 2024. This is purely due to the long training period required to become a doctor.

This study reckons that there is no acute necessity for opening up of anymore private or state medical schools 
in the country, as of now, because Sri Lanka will have the needed number of doctors by $2025 / 2026$. Moreover, even if $10 \%$ more than the need is added to minimise maldistribution, Sri Lanka would have enough doctors by 2029 .

However, a comprehensive health workforce analysis of this nature will have to be done every 5 years and the intake adjusted according to the country's requirement. Furthermore, there should be a mechanism to regulate the large number of students going abroad to study Medicine. Public awareness about the supply and need for doctors in the country should be enhanced.

\section{Conflicts of interest}

Author declares thet there are no conflicts of interest.

\section{References}

1. Health Economics Cell, Ministry of Health, Nutrition \& Indigenous Medicine Sri Lanka 2016. Sri Lanka National Health Accounts 2013, Ministry of Health Colombo Sri Lanka

2. Family Health Bureau Colombo Sri Lanka. Available at: http://fhb.health.gov.lk/web/index. php?option $=$ com

3. University Grant Commission Colombo Sri Lanka, Available at http://www.ugc.ac.lk/en/component/ content/article/1709-sri-lanka-university-statistics2015.html (Accessed on 3.03.2017)

4. Sri Lanka Medical Council 2016. Available at: http://www.srilankamedicalcouncil.org/erpm.php (Accessed on 04.02.2017)

5. Bratton, J. and Jeffrey, G..Human Resource management- Theory and Practice.3rd ed. New York: Palgrave Macmillan, 2003

6. Lane, D.C., System Dynamics Modelling of Patient flows through Acute Hospitals. Report for the NHS Executive: London. 1999
7. Forrester, J.W., System dynamics - the next fifty years. System Dynamics Review, 2007;23(2-3):359370

8. Sterman JD. System Dynamics Modeling: Tools for Learning in a Complex World. California Management Review 2001; 43:8-25

9. Sri Lanka's Health Challenges -The Economist Intelligence, 2014. Available at: www.country.eiu.com/article. aspx?articleid $=1502512534 \&$ Country $=$ Sri\%20Lanka (Accessed on 23.03.2017).

10. South Asian Institute of Technology and Medicine. Available at : http://www.saitm.edu.lk/ (Accessed on 14.04.2017)

11. Ministry of Health Sri Lanka. Available at: http:// www.health.gov.lk/moh. (Accessed on 15.06.2017)

12. Official websites of the 8 Medical Faculties and Kotalawela Defense University, Sri Lanka. Available at: http://www.med.cmb.ac.lk/, http://med.pdn. ac.lk/, http://medicine.kln.ac.lk/, http://medical.sjp. ac.lk/, http://www.medi.ruh.ac.lk/, http://www.rjt. ac.lk/med/, http://www.rjt.ac.lk/med/, http://www. med.jfn.ac.lk/, http://www.kdu.ac.lk (Accessed on 17.01.2017)

13. Koelling, P. and Schwandt, M., 2005. Health Systems: A Dynamic System - benefits from System Dynamics. Proceedings of the 2005 Winter Simulation Conference, Orlando, FL.

14. Royston, G., Using system dynamics to help develop and implement policies and programmes in health care in England. System Dynamics Review, 1999;15(3): 2893-313

15. World Health Organization. Available at: http://www.who.int/workforcealliance/ countries/57crisiscountries.pdf (Accessed 10.01.2017) 